\title{
PELUANG DAN TANTANGAN ATAS KEIKUTSERTAAN INDONESIA DALAM MASYARAKAT EKONOMI ASEAN
}

\author{
Inda Rahadiyan", Karina Amanda Savira²
}

\begin{abstract}
Abstrak : Permasalahan yang dikaji dalam penelitian ini adalah bagaimana peluang dan tantangan yang dihadapi oleh Indonesia dalam Masyarakat Ekonomi ASEAN (MEA)? Penelitian dilakukan dengan menggunakan metode studi kepustakaan (library research). Hasil penelitian menunjukkan bahwa terdapat beberapa faktor penting yang menjadi peluang sekaligus tantangan bagi Indonesia dalam keikusertaan MEA, di antaranya adalah faktor jumlah penduduk dan faktor letak geografis.
\end{abstract}

Kata-kata kunci: Masyarakat Ekonomi ASEAN, peluang, tantangan

\section{PENDAHULUAN}

Komitmen para pemimpin negara Asia Tenggara dalam rangka membentuk masyarakat ASEAN (ASEAN Community) sebagaimana tercantum di dalam Visi ASEAN $2020^{1}$ telah memasuki tahapan baru pasca tercapainya kesepakatan pembentukan Masyarakat Ekonomi ASEAN (MEA) pada pertemuan Bali Concord II. ${ }^{2}$ Berbagai pertemuan terkait pembentukan MEA terus dilakukan secara berkesinambungan oleh para pemimpin negara ASEAN. Salah satu hasil kesepakatan penting yang dicapai adalah mengenai

$$
\text { percepatan }
$$

rencana

Penulis

1. Penulis menyelesaikan pendidikan Strata Satu dan Strata Dua pada Fakultas Hukum Universitas Gadjah Mada. Kini penulis adalah Dosen Tetap pada Fakultas Hukum Universitas Islam Indonesia.

2. Penulis adalah mahasiswa aktif pada Fakultas Hukum Universitas Islam Indonesia.

1 Mengenai ini baca: ASEAN Vision 2020, http://www.aseansec.org/1814.htm

2 Mengenai ini baca: Bali Concord $\mathrm{II}_{2}$ http://www.aseansec.org/15159.htm pembentukan MEA yang semula diagendakan pada tahun 2020 kemudian disepakati akan dilaksanakan pada tahun 2015. ${ }^{3}$

Sebagai suatu bentuk liberalisasi ekonomi regional, MEA memiliki karakteristik utama yang meliputi; (1) pasar tunggal dan basis produksi tunggal, (2) kawasan ekonomi yang berdaya saing tinggi, (3) kawasan dengan pembangunan ekonomi yang merata, serta (4) kawasan yang terintegrasi penuh dengan ekonomi global. ${ }^{4}$ Berdasarkan pada karakteristik yang demikian maka sistem perekonomian kawasan Asia Tenggara akan benar-benar menyatu dengan sistem perekonomian global. Integrasi sistem perekonomian dalam konteks demikian tentu memiliki implikasi terhadap peluang

3 Kesepakatan ini dicapai pada KTT ASEAN ke-12 bulan Januari tahun 2007.

4 ASEAN Economic Community Blueprint, http:www.//asean.org 
dan tantangan yang dihadapi oleh setiap negara anggota termasuk Indonesia.

Tujuan utama yang hendak dicapai melalui pembentukan MEA adalah terwujudnya pasar tunggal (single market) dan basis produksi tunggal (production base) yang terintegrasi secara penuh dengan perekonomian global. ${ }^{5}$ Dalam kaitan ini, aliran bebas barang merupakan salah satu instrumen utama bagi terbentuknya pasar tunggal itu sendiri. Aliran bebas barang akan terwujud melalui berbagai aktivitas perdagangan dengan melibatkan baik para pelaku usaha yang berasal dari dalam kawasan ASEAN maupun dari luar kawasan ASEAN, sehingga pemberlakuan MEA akan semakin mendorong terjadinya globalisasi ekonomi. Globalisasi ekonomi kemudian dihadapkan pada berbagai faktor yang menjadi peluang sekaligus tantangan bagi setiap negara anggota. ${ }^{6}$ Keikutsertaan Indonesia dalam MEA setidaknya dihadapkan pada beberapa faktor penting yang dapat dipandang sebagai peluang sekaligus tantangan. Di antaranya yakni faktor letak geografis, jumlah penduduk serta pertumbuhan kelas menengah. Pertama, Indonesia merupakan negara dengan penduduk

\footnotetext{
${ }^{5}$ Ibid.

6 Baca: "Peranan Hukum dalam Pembangunan Pada Era Globalisasi: Implikasinya Bagi Pendidikan Hukum di Indonesia", Pidato Pengukuhan Jabatan Guru Besar dalam Bidang Hukum Pada Fakultas Hukum Universitas Indonesia, Jakarta, 4 Januari 1997, http://www.ermanhukum.com Diakses pada tanggal 07 Februari 2015, pukul 13.34 WIB.
}

terbesar di kawasan ASEAN. Berdasarkan data Biro Pusat Statistik, penduduk ASEAN mencapai angka lebih dari 600 juta jiwa dengan populasi penduduk Indonesia mencapai 237.641.326 per tahun 2010.7 Kedua, secara geografis letak Indonesia sangat strategis di kawasan ASEAN. Posisi Indonesia yang berada pada jalur lalu lintas perdagangan berpotensi memberikan peluang bagi kemajuan perekonomian. $\mathrm{Di}$ sisi lain, faktor lokasi geografis ini justru dapat menimbulkan tantangan seperti kemungkinan masuknya produk-produk selundupan/ilegal melalui berbagai pelabuhan. ${ }^{8}$ Ketiga, pertumbuhan kelas menengah (middle class) di Indonesia dapat dikatakan kian meningkat dari waktu ke waktu. Pertumbuhan kelas menengah ini tentunya dapat memberikan pengaruh positif bagi daya saing Indonesia di tingkat regional maupun global. Berdasarkan latar belakang sebagaimana telah diuraikan, maka pengkajian mengenai peluang dan tantangan bagi Indonesia dalam keikutsertaan MEA menjadi suatu hal yang penting untuk dilakukan.

7 Badan Pusat Statistik Republik Indonesia, "Indikator Sosial Budaya 2003, 2006, 2009, 2012", http://www.bps.go.id, diakses pada tanggal 05 Februari 2015 pukul 16.05 WIB.

8 Untuk ini baca: Adrini Pujayanti, "Budaya Maritim, Geo-Politik dan Tantangan Keamanan Indonesiam Bagian Ke Satu", http://www.berkas.dpr.go.id, diakses pada tanggal 15 Februari 2015, pukul 13.05 WIB. 


\subsection{Rumusan Masalah}

Penelitian ini dilakukan dalam rangka menjawab sebuah rumusan masalah yakni bagaimana peluang dan tantangan yang dihadapi Indonesia atas keikutsertaan Indonesia dalam MEA?

\subsection{Tujuan Penelitian}

Penelitian ini bertujuan untuk mengkaji peluang dan tantangan yang dihadapi Indonesia atas keikutsertaan Indonesia dalam MEA.

\subsection{Metode Penelitian}

Metode penelitian yang digunakan dalam rangka menjawab rumusan masalah dalam dalam kajian ini adalah studi kepustakaan (library research). Studi kepustakaan dilakukan dengan mengumpulkan, membaca, serta mengkaji berbagai sumber kepustakaan yang relevan guna menjawab permasalahan penelitian. $^{9}$

\section{PEMBAHASAN}

\section{Kedudukan MEA Sebagai Salah Satu} Bentuk Liberalisasi Ekonomi Regional

'Interdependence" may be overused but it accurately describes our world today. Economic forces flow with great rapidity from one country to the next. Despite all the talk about

${ }^{9}$ Baca Johny Ibrahim, Teori dan Metodologi Penelitian Normatif, 2006, Malang, Bayumedia Publishing. sovereignty and independence, in the fact these concepts can mislead and irrelevant when applied to the today's world economy. ${ }^{10}$

Kutipan ini memberikan gambaran jelas mengenai kondisi perekonomian dunia dewasa ini yang menunjukkan adanya ketergantungan antar negara terlebih sejak kemunculan dan berkembangnya arus globalisasi. Saling ketergantungan (interdependensi) antarnegara pada tataran selanjutnya telah mendorong terjadinya penyatuan (integrasi) ekonomi baik dalam skala global maupun dalam skala regional.

Integrasi perekonomian dunia akan diikuti oleh harmonisasi hukum. Secara historis terbentuknya World Trade Organization (WTO) didahului oleh terbentuknya blok-blok ekonomi regional seperti Masyarakat Ekonomi Eropa (European Union), NAFTA, AFTA, serta APEC. Dengan demikian, tidak ada kontradiksi antara regionalisasi dengan globalisasi perdagangan. Sebaliknya, integrasi ekonomi global telah mendorong terciptanya blok-blok perdagangan baru. ${ }^{11}$

Berbicara tentang liberalisasi ekonomi regional di kawasan Asia Tenggara tentu tidak dapat terlepas dari

10 John H. Jackson, William J. Davey and Alan O. Sykes. Legal Problems of International Economic Relations. 2002. West Group. ST Paull Minn., hlm.1.

11 Bary Hufbauer, "International Trade Organization and Economies in Transition: $A$ Glimpse of The Twenty-First Century", Law and Policy in International Business, Vol.29, 1995, hlm.108 
pembicaraan mengenai pembentukan Masyarakat Ekonomi ASEAN (MEA). Cikal bakal kerjasama ekonomi negaranegara Asia Tenggara diawali dengan kesepakatan pembentukan kawasan perdagangan bebas ASEAN (ASEAN Free Trade Area/AFTA) pada tahun 1992 yang meliputi kesepakatan di bidang perdagangan barang. Langkah liberalisasi kemudian dilanjutkan melalui kesepakatan kerjasama perdagangan bidang jasa (ASEAN Framework Agreement on Services) pada tahun 1993 dan kesepakatan bidang investasi (ASEAN Investment Area) pada tahun 1998.

Upaya pembentukan integrasi ekonomi di kawasan Asia Tenggara kemudian mencapai puncaknya melalui kesepakatan pembentukan ASEAN Economic Community (AEC/MEA) pada tahun 2003. ${ }^{12}$ MEA dibentuk dal am rangka menciptakan kawasan Asia Tenggara sebagai sebuah pasar tunggal (single market) dan basis produksi tunggal (production base) melalui pembebasan aliran barang, jasa, tenaga kerja terampil (skilled labor) serta arus penanaman modal yang lebih bebas (freer flow of capital) antar negara anggota. ${ }^{13}$

Percepatan pembentukan MEA disepakati dalam KTT ASEAN ke-12 yang

12 Chia, S.Y., 2013, "The ASEAN Economic Community: Progress, Challenges and Prospects", ADBI Working Paper 440. Tokyo: Asian Development Bank Institute, hlm. 1, http://www.adbi.org, diakses pada tanggal 03 Februari 2015 pukul 14.40 WIB. Blueprint, Loc. Cit. diselenggarakan pada bulan Januari 2007 melalui penandatanganan "Declaration on the Acceleration of the Establishment of an ASEAN Community by 2015". Sebagai tindak lanjut atas kesepakatan tersebut, para Menteri Ekonomi ASEAN kemudian menginstruksikan kepada Sekretariat ASEAN untuk menyusun sebuah Cetak Biru ASEAN Economic Community ${ }^{14}$ yang memuat empat pilar utama:

ASEAN sebagai pasar tunggal dan basis produksi tunggal yang didukung dengan elemen aliran bebas barang, jasa, tenaga kerja terdidik dan aliran modal yang lebih bebas;

(2) ASEAN sebagai kawasan yang berdaya saing tinggi di bidang ekonomi dengan elemen peraturan kompetisi, perlindungan konsumen, hak atas kekayaan intelektual, pengembangan infrastruktur, perpajakan dan e-commerce;

(3) ASEAN sebagai kawasan pengembangan ekonomi yang bersifat merata dengan elemen pengembangan usaha kecil dan menengah serta prakarsa integrasi ASEAN untuk negara-negara Kamboja, Laos, dan Vietnam;

(4) ASEAN sebagai kawasan yang terintegrasi penuh dengan perekonomian global.

Kerjasama ekonomi MEA meliputi dua belas (12) sektor prioritas yakni: produk-

\footnotetext{
14 Dian Triansyah Djani, "ASEAN Selayang Pandang", Direktur Jendral Kerjasama ASEAN, Jakarta, hlm. 33.
} 
produk berbasis pertanian, otomotif, elektronik, perikanan, produk berbahan dasar karet, tekstil, produk berbahan dasar kayu, jasa perjalanan udara, eASEAN, bidang kesehatan, pariwisata, serta logistik. ${ }^{15}$ Dalam rangka menyongsong era perdagangan bebas ASEAN pada kedua belas (12) sektor sebagaimana telah disepakati, Indonesia telah menerbitkan sebuah regulasi penting yakni Undang-Undang Nomor 7 Tahun 2014 tentang Perdagangan (UndangUndang Perdagangan). Pembentukan undang-undang ini merupakan salah satu upaya yang dilakukan oleh pemerintah untuk mencegah dampak negatif atas masuknya berbagai produk impor menyusul berlakunya MEA 2015. ${ }^{16}$ Undang-Undang Perdagangan mengatur berbagai materi muatan penting di antaranya mengenai: aturan umum perizinan bagi pelaku usaha yang terlibat dalam kegiatan perdagangan ${ }^{17}$, peningkatan penggunaan produk dalam negeri ${ }^{18}$ serta larangan pembatasan

\section{Blueprint, Loc.cit.}

${ }^{15}$ ASEAN Economic Community

16 Humprey Wangke, "Peluang Indonesia dalam Masyarakat Ekonomi ASEAN 2015", Bidang Hubungan Internasional, Pusat Pengkajian, Pengolahan Data dan Informasi (P3DI) Setjen DPR RI, http://www.dpr.go.id, diakses pada tanggal 12 Februari 2015, pukul 17.10 WIB.

$\begin{array}{llll} & & \\ & \text { Pasal } & \text { Undang-Undang Nomor } 7 \\ \text { Tahun } 2014 & \text { tentang Perdagangan } \\ \text { mewajibkan pelaku usaha } & \text { untuk } \\ \text { menggunakan atau melengkapi label } & \text { lau } \\ \text { berbahasa Indonesia pada barang yang } \\ \text { diperdagangkan di dalam negeri. } \\ 18 \text { Pasal } 22 \text { Undang-Undang Nomor } 7\end{array}$
Tahun 2014 tentang Perdagangan barang dan jasa bagi kepentingan nasional. ${ }^{19}$

Selain itu, kerjasama ekonomi MEA juga mencakup berbagai bidang yang meliputi pengembangan sumber daya manusia dan peningkatan kapasitas, pengakuan kualifikasi profesional, konsultasi kebijakan ekonomi makro dan keuangan, tahapan pembiayaan perdagangan, peningkatan infrastruktur dan konektivitas komunikasi, pengembangan transaksi elektronik melalui e-ASEAN, integrasi industri kawasan dalam rangka promosi sumber daya daerah, serta peningkatan peran serta sektor swasta dalam pembangunan MEA. ${ }^{20}$

\section{Peluang dan Tantangan Atas Keikutsertaan Indonesia dalam Masyarakat Ekonomi Asean}

Indonesia sebagai salah satu negara penggagas berdirinya ASEAN ${ }^{21}$

${ }^{19}$ Baca: Pasal 35, Pasal 36 dan Pasal 37 Undang-Undang Nomor 7 Tahun 2014 tentang Perdagangan

20 Mohamed Jawar Hasan, The Resurgence of China and India, Major Power Rivalry and The Response of ASEAN, dalam Hadi Soesastro dan Clara Joewon, The Inklusif Regionalist, Jakarta, Centre for Strategic and International Studies Indonesia, 2007, dalam Masnur Tiurmaida Malau, "Aspek Hukum Peraturan dan Kebijakan Pemerintah Indonesia Menghadapi Liberalisasi Ekonomi Regional: Masyarakat Ekonomi Asean 2015", Jurnal Recht Vinding, Volume 3 Nomor 2, Agustus 2014,hlm. 165.

${ }^{21}$ ASEAN didirikan pada tahun 1967 oleh lima negara penggagas yakni; Indonesia, Malayasia, Filipina, Singapura dan Thailand. Pada awal pendiriannya, ASEAN bertujuan untuk meningkatkan kerjasama ekonomi dan politik antar negara anggota sehingga pada 
tentu memiliki peran penting bagi kemajuan kerjasama antarnegara anggota. Dalam rangka menyongsong pemberlakuan MEA, pengetahuan mengenai peluang dan tantangan yang dihadapi oleh Indonesia menjadi sangat relevan terutama guna menentukan arah kebijakan dan strategi menghadapi era liberalisasi ekonomi regional ini.

Beberapa faktor yang merupakan peluang sekaligus tantangan bagi Indonesia dalam rangka menyongsong pemberlakuan MEA 2015 terutama berkaitan dengan tiga hal, yakni; jumlah penduduk, lokasi geografis, serta pertumbuhan kelas menengah. Pertama, Indonesia merupakan negara dengan penduduk terbesar di kawasan ASEAN. Berdasarkan data Badan Pusat Statistik, penduduk ASEAN mencapai angka lebih dari 600 juta jiwa dengan populasi penduduk Indonesia mencapai 237.641.326 per tahun 2010. ${ }^{22}$

Jumlah penduduk yang demikian besar menunjukkan adanya ketersediaan tenaga kerja sekaligus pangsa pasar yang

saat itu permasalahan mengenai integrasi ekonomi regional (liberalisasi ekonomi regional) belum mengemuka. Mengenai hal ini baca: Suthipand Chirativat, Chumpron Pachusanond dan Patcharawalai Wongboonsin, "ASEAN Prospects for Regional Integration and the Implications for the ASEAN Legislative and Institutional Framework", ASEAN Economic Bulletin, Vol.16 No.1 April 1999, Institute of Southeast Asian Studies (ISEAS), http://www.jstor.org/stable/25773558, hlm. 29.

22 Badan Pusat Statistik Republik Indonesia, "Indikator Sosial Budaya 2003, 2006, 2009, 2012", http://www.bps.go.id, diakses pada tanggal 05 Februari 2015 pukul 16.05 WIB. menjanjikan. Dalam konteks MEA, faktor jumlah penduduk ini mampu memberikan sebuah peluang bagi Indonesia apabila dikelola dan dipersiapkan dengan baik oleh para pemangku kepentingan. Akan tetapi , faktor jumlah penduduk ini juga dapat menjadi tantangan manakala tidak dikelola dan dipersiapkan dengan baik. Tanpa diikuti dengan berbagai upaya pembangunan sumber daya manusia, faktor jumlah penduduk ini ini dikhawatirkan justru hanya akan menjadikan Indonesia sebagai 'pasar' terbesar di kawasan Asia Tenggara.

Kedua, sebagaimana diketahui bahwa Indonesia terletak pada posisi geografis sangat strategis di kawasan ASEAN. Posisi Indonesia yang berada pada jalur lalu lintas perdagangan berpotensi memberikan peluang bagi kemajuan perekonomian. Faktor letak geografis ini dapat menjadi peluang apabila dimaksimalkan melalui berbagai upaya seperti pembangunan kawasan pelabuhan dan pembangunan infrastruktur yang mampu menjadi penghubung antar kawasan. Akan tetapi, perlu untuk dipahami pula bahwa pada sisi yang lain faktor lokasi geografis ini justru dapat menimbulkan tantangan seperti masuknya produk-produk selundupan/ilegal melalui berbagai pelabuhan. ${ }^{23}$

23 Untuk ini baca: Adrini Pujayanti, "Budaya Maritim, Geo-Politik dan Tantangan Keamanan Indonesiam Bagian Ke Satu", http://www.berkas.dpr.go.id, diakses pada tanggal 15 Februari 2015, pukul 13.05 WIB. 
Ketiga, pertumbuhan kelas menengah (middle class) di Indonesia yang kian meningkat dari waktu ke waktu. Pertumbuhan kelas menengah ini tentunya dapat memberikan pengaruh positif bagi daya saing Indonesia di tingkat regional maupun global. Hal demikian dapat dipahami mengingat pertumbuhan kelas menengah akan berkorelasi positif dengan minat investor untuk menjadikan Indonesia sebagai negara tujuan investasinya. Secara garis besar peluang yang dimiliki oleh Indonesia dalam menyongsong pemberlakuan MEA 2015, antara lain meliputi:

(1) Peluang sebagai pasar potensial dunia

Dengan jumlah penduduk terbesar ${ }^{24}$ di kawasan Asia Tenggara, Indonesia berpotensi menjadi pemimpin ekonomi ASEAN. Jumlah penduduk yang besar dan heterogen selain menjadikan Indonesia sebagai pasar potensial juga menjadikan Indonesia sebagai negara penyedia tenaga kerja terbesar di kawasan Asia Tenggara. ${ }^{25}$

(2) Peluang sebagai negara tujuan investasi

Indonesia merupakan negara tujuan investasi di kawasan Asia Tenggara. Prosentase jumlah investasi negara anggota ASEAN di Indonesia tercatat

${ }^{24}$ Terhitung hingga tahun 2010 jumlah penduduk Indonesia mencapai 237.641.326 dari total penduduk ASEAN mencapai 633,1 juta jiwa. Lihat: http://www.bps/go.id hlm. 171. mencapai $43 \%^{26}$ dari total investasi negara-negara ASEAN di negara lain.

(3) Peluang sebagai negara pengekspor

Berdasarkan nilai ekspor Indonesia menuju negara di luar kawasan ASEAN yang mencapai lebih dari $80 \%$ dari total kegiatan ekspor yang dilakukan maka terbuka peluang besar bagi Indonesia untuk menjadi negara pengeksor besar di kawasan Asia Tenggara. ${ }^{27}$

(4) Peluang yang disebabkan oleh bonus demografi

Sebagai negara yang memiliki jumlah populasi terbesar di kawasan Asia Tenggara ${ }^{28}$ maka Indonesia berpeluang meningkatkan pendapat per kapita berdasarkan pada perhitungan jumlah penduduk usia produktif. Penduduk usia produktif diharapkan dapat turut menopang pertumbuhan ekonomi yang pada akhirnya akan berkorelasi positif

26 Peningkatan jumlah investasi di kawasan Asia Tenggara ini terutama dipengaruhi oleh dilakukannya penghapusan hambatan investasi (investment barriers) melalui kesepakatan ASEAN Investment Area (AIA). Lebih lanjut mengenai AIA baca: "ASEAN Investment Area", http://www.asean.org.

27 Erman Rajagukguk, "ASEAN-China Free Trade Area Agreement dan Implikasinya bagi Indonesia", http://www.ui.ac.id/lib.ui.ac.id, diakses pada tanggal 07 Februari 2015 pukul 10.49 WIB.

28 Perbandingan jumlah penduduk usia produktif di Indonesia dengan negara ASEAN lainnya yakni 38:100 yang berarti bahwa di dalam setiap 100 orang penduduk ASEAN usia produktif maka 38 di antaranya adalah penduduk Indonesia. Lihat: "Komunitas ASEAN 2015", http://www.setneg.go.id/index.php/option, diakses pada tanggal 07 Februari 2015 pukul 10.53 WIB. 
dengan kemampuan daya saing menghadapi MEA 2015 29 disamping pembicaraan mengenai peluang dan tantangan, pembicaraan mengenai kesiapan Indonesia dalam menyongsong pemberlakuan MEA 2015 juga menjadi suatu hal yang tidak kalah penting untuk disinggung. Mengenai upaya persiapan dalam rangka menyongsong pemberlakuan MEA, Hendri Saparini menyatakan bahwa kesiapan Indonesia baru mencapai 82 persen. Kondisi ini ditengarai dari empat isu penting yang perlu segera diantisipasi oleh Pemerintah. Keempat isu tersebut, yakni: ${ }^{30}$

(1) Indonesia berpotensi untuk sekedar menjadi pemasok energi dan bahan baku bagi proses industrialisasi di kawasan ASEAN. Hal ini mengakibatkan minimnya manfaat yang diperoleh dari kekayaan sumber daya alam dan defisit neraca perdagangan;

(2) Meningkatnya defisit perdagangan barang seiring dengan meningkatnya perdagangan jasa;

(3) Pembebasan aliran tenaga kerja dapat mengakibatkan 'membanjirnya' tenaga kerja asing;

${ }^{29}$ Masnur Tiurmaida, Op.cit., hlm 172. ${ }^{30}$ Humprey Wangke, Op.cit., hlm. 8.
(4) Arus investasi ke dalam negeri Indonesia baik yang berasal dari dalam maupun dari luar kawasan ASEAN.

(5)

\section{PENUTUP}

Terdapat beberapa faktor yang merupakan peluang sekaligus tantangan bagi Indonesia atas keikutsertaan Indonesia dalam MEA. Ketiga faktor dimaksud, yakni; (1) faktor letak geografis, (2) faktor jumlah penduduk, serta (3) faktor pertumbuhan penduduk kelas menengah. Pemerintah Indonesia bersama dengan para pemangku kepentingan diharapkan dapat mengelola berbagai peluang yang ada dalam rangka menghadapi era perekonomian bebas ASEAN (MEA).

\section{DAFTAR PUSTAKA BUKU}

John $\mathrm{H}$. Jackson, William J. Davey and Alan O. Sykes. Legal Problems of International Economic Relations. 2002. West Group. ST Paull Minn.

Johny Ibrahim, Teori dan Metodologi Penelitian Normatif, 2006, Malang, Bayumedia Publishing.

Nopirin, Ekonomi Internasional, Edisi 3, 2011, Badan Penerbitan Fakultas Ekonomika dan Bisnis (BPFE) Universitas Gadjah Mada.

Peter Van Den Bosche, 2007, the Law and Policy of the World Trade Organization Text, Cases and Materials, Cambridge University Press.

\section{JURNAL}

Bary Hufbauer, "International Trade Organization and Economies in 
Transition: A Glimpse of the TwentyFirst Century", Law and Policy in International Business, Vol.29, 1995, HIm.108

\section{DATA ELEKTRONIK}

Adrini Pujayanti, "Budaya Maritim, GeoPolitik dan Tantangan Keamanan Indonesiam Bagian Ke Satu", http://www.berkas.dpr.go.id

Anonim, "Komunitas ASEAN 2015", http://www.setneg.go.id/index.php/o ption

Anonim, ASEAN Investment Area", http://www.asean.org.

ASEAN Economic Community Blueprint, http:www.//asean.org

ASEAN Vision 2020, http://www.aseansec.org/1814.htm

Badan Pusat Statistik Republik Indonesia, "Indikator Sosial Budaya 2003, 2006, 2009, 2012", http://www.bps.go.id

Bali Concord

$\mathrm{II}_{2}$ http://www.aseansec.org/15159.htm

Chia, S.Y., 2013, "The ASEAN Economic Community: Progress, Challenges and Prospects", ADBI Working Paper 440. Tokyo: Asian Development Bank Institute, http://www.adbi.org

Dian Triansyah Djani, "ASEAN Selayang Pandang", Direktur Jendral Kerjasama ASEAN
Erman Rajagukguk, "ASEAN-China Free

Trade Area Agreement dan Implikasinya bagi Indonesia", http://www.ui.ac.id/lib.ui.ac.id

Erman Rajagukguk, "Peranan Hukum dalam Pembangunan Pada Era Globalisasi: Implikasinya Bagi Pendidikan Hukum di Indonesia", Pidato Pengukuhan Jabatan Guru Besar dalam Bidang Hukum Pada Fakultas Hukum Universitas Indonesia, Jakarta, 4 Januari 1997, http://www.ermanhukum.com

Humprey Wangke, "Peluang Indonesia dalam Masyarakat Ekonomi ASEAN 2015", Bidang Hubungan Internasional, Pusat Pengkajian, Pengolahan Data dan Informasi (P3DI) Setjen DPR RI, http://www.dpr.go.id

Suthipand Chirativat, Chumpron Pachusanond dan Patcharawalai Wongboonsin, "ASEAN Prospects for Regional Integration and the Implications for the ASEAN Legislative and Institutional Framework", ASEAN Economic Bulletin, Vol.16 No.1 April 1999, Institute of Southeast Asian Studies (ISEAS),

http://www.jstor.org/stable/25773558 